\title{
Capital Budgeting Methods Used in Some European Countries and in the United States
}

\author{
Klara, Szucsne Markovics \\ Faculty of Economics, Institute of Business Sciences, University of Miskolc, Hungary
}

Copyright $\mathrm{C} 2016$ by authors, all rights reserved. Authors agree that this article remains permanently open access under the terms of the Creative Commons Attribution License 4.0 International License

\begin{abstract}
This paper provides a comprehensive overview of capital budgeting methods preferred by corporate managers in some European countries and in the United States. On the basis of international research findings and our empirical survey, three important observations can be made: (1) a considerable amount of European and US corporations calculate the indicator of the payback period; (2) the net present value and the internal rate of return are the two most frequently used discounted cash-flow methods; (3) companies in France and Hungary used the profitability index more often than companies in other surveyed countries.
\end{abstract}

Keywords Capital Budgeting, Project Valuation, Investment Decisions, Net Present Value, Internal Rate of Return, Payback Period

\section{Introduction}

Both international and Hungarian literature offers numerous capital budgeting methods that can be put into the practice of enterprises in a satisfactory or less satisfactory way. Empirical research studies have been conducted in many countries to reveal which of the methods recommended by the literature are used most frequently by corporate decision-makers in the phase of the decision-preparation process of investments.

Taking into consisderation the findings of international and national research studies in the area of investment, this paper aims to give a comprehensive review of capital budgeting methods that are most frequently used by corporate decision-makers in Europe and in the US. The importance of this paper is that it compares methods applied by companies in the United States and in Europe. This paper contributes to topic of investigation of corporate investment decisions and includes results of a research study conducted in Hungary. (Since there are very few research studies that investigate investment decisions at a corporate level in Hungary, there are hardly any publications related to the applied methods of capital budgeting in this country.)

In some countries such as the United Kingdom, Finland and the Netherlands, several research studies have been conducted into investment decisions, which enable academics to examine the changes in investment trends within a country. However, it has to be noted that conflicting and even contradictory results were obtained even in surveys conducted in the same year. A typical example of this is the findings of 12 empirical research studies on corporate investment decisions, with special attention to capital budgeting methods applied in the decision-preparation phase of investments between 1966 and 1989 in the UK. In 1986 major British corporations were surveyed. On the basis of 131 responses, Mills and Herbert [1] came to the conclusion that only $52 \%$ of the companies in the United Kingdom used discounted cash-flow techniques, whereas in Pike's survey [2] consisting of 100 responses the number of companies using this technique was considerably higher and amounted to $84 \%$.

This study investigates the findings of our empirical research and compares them with the results of international research studies conducted in this issue and published in English. In the course of the evaluation and interpretation of findings, special attention was paid to the following issues:

- A representative approach often fails to give a clear picture about the topic of research, which results in rather superficial knowledge of applied research methods.

- The evaluation of the empirical surveys on capital budgeting practices preferred by companies showed that the applied research methodology was extremely heterogeneous. Most surveys used questionnaires which were supplemented by oral interviews in some cases. Phone and e-mail surveys were also conducted.

- The range of the sampled enterprises involved in the surveys under analysis was quite wide. Companies differed along size dimensions. Most surveys were conducted on corporations, most of which were listed in the stock exchange of their countries. Few surveys were conducted on small and medium-sized enterprises. There were even surveys in which the size of the 
sampled companies was irrelevant.

- As for the element number of the samples, there were surveys with hundreds of respondents and there were some with less than one hundred.

- As for the sectors of industry, the surveys did not show a single picture. There were surveys conducted in a wide range of companies belonging to different sectors, whereas some surveys excluded companies providing financial services, while the others targeted only the manufacturing industry or limited their scope to a few sectors.

- This study investigates capital budgeting indicators preferred by corporate executives as they are termed. However, the content lying behind the terms is not likely to have been standardised. There are primarily two reasons for this. The first one is related to the quantification of certain methods. Since the available theoretical literature sometimes offers different approaches, for instance in the case of the calculation of net present value, there are papers which offer the application of both gross cash flow and net cash flow. The second reason is that the quantfication of indicators may be different in corporate practices and vary from country to country. The reviewed research studies provide different explainations regarding the calculations of the indicator in question in different countries.

- The reviewed research studies can be divided into two groups taking into consideration the number of indicators that are considered important and the frequency of their usage: some researchers investigated only the most frequently used indicators (5-6), while the others examined almost all the indicators (as many as $10-12$ ).

In order to ensure greater clarity, this paper investigated the usage of only five indicators which were recommended in the available literature and applied by most researches (payback period, accounting rate of return, internal rate of return, net present value and profitability index) in some European countries and in the US.

\section{Methods Recommended in the Literature}

Capital budgeting methods involves a long decision-preparation process of investments. These methods have a well-established methodology discussed in detail both in the international and national literature. In the past non-discounted cash flow methods- that disregarded the time value of money principle- were frequently applied in order to evaluate the economic efficiency of investment projects. In the 1930s, the calculation of the net present value and other discounted cash-flow methods were introduced firstly in the books and articles of Anglo-Saxon authors.

Since non-discounted indicators can be calculated relatively easily and quickly, they are frequently used in corporate practices. According to the most generally used formula of non-discounted calculations, an investment can be regarded as economic if its profitability is not lower than the amount its investor expects in return on the basis of the discount rate. There are several other methods to determine the accounting rate of return in the economic literature where the average annual (pre-tax or after-tax) return appears in the numerator of the formula and the average investment or average capital employed can be found in the denominator.

Studies also deal with a payback period which can be defined as the reciprocal of the accounting rate of return. It shows the time duration required to realize returns on the investment into a project. Illés [3] draws the attention to the problem hidden in the calculation of the payback period: 'The method, albeit mathematically utterly correct, is not too fortunate. It suggests that the return of the invested amount from the profit is an obvious correspondence in Economics but this is far from being true. The set of conditions of the static analysis in question, which covers the whole life cycle, directly states that the life cycle of the investment is infinite. As such, by its content, neither it nor its face value has to return from the profit. Such a requirement can also be deducted simply formally.' (Illés [3], p. 122.)

One of the most frequently recommended capital budgeting methods is the calculation of net present value. Net present value is an index basically expressing difference; its general formula shows the resulting surplus profit converted into net present value - of the investment above the normally expected profitability (or the yield loss compared with the expected return). A significant part of the English sources shed a favourable light on the calculation of the net present value. For instance, Brealey and Myers [5] (1981) devoted a whole chapter in their book, Principles of Corporate Finance to the question of 'why the calculation of net present value leads to better investment decisions than other criteria.' (Brealey and Myers [4], pp. 61-82.)

By rearranging the formula of the net present value, we obtain another index, which is most frequently termed as profitability index in the literature. One of the greatest disadvantages of this index results from the fact that it is difficult to interpret. Contrary to its name, it does not show the actual profitability of an investment. Accordingly, it provides information only on the question whether the amount of revenue converted into present value equals to the present value of expenses, or rather, whether the net present value of net yield equals to the present value of the invested amount. Another problem of this index is that it does not take into account how many years are required and how much tied-up capital is needed to realize the rate of the net yield converted into the present value. [3]

Internal rate of return is also a frequently recommended capital budgeting method for qualifying the efficiency of investments, which is a rate of return at which the net present value of costs of the investment equals the net present value of the benefits of the investment. The internal rate of return shows the actual profitability of an investment. Unlike the 
other discounted cash-flow techniques, it has the advantage that the end sum of the calculation can be easily understood by corporate decision-makers, furthermore, the information it provides is not distorted by the uncertainty about the definition of discount rate.

The discounted payback period shows that in addition to a given discount rate of profitability expectations, how many years are needed for the discounted amounts related to investment and non-investment expenses to pay off from the discounted amounts of investment proceeds. It is calculated as follows: by making the lines of revenues and expenditures equal, we look for the year when the discounted amounts related to investment and non-investment expenses first return from the discounted amounts of the proceeds of the investment, that is, the discounted payback period can be defined by finding the year that solves the net present value formula to zero.

To conclude, capital budgeting has got a complex and sophisticated methodology as well as abundant literature. Most authors review payback period, accounting rate of return, net present value, internal rate of return, profitability index and discounted payback period as the most common capital budgeting methods in their books but other methods can also be found in the literature such as the calculation of benefit-cost ratio. (Due to space constraints, I do not wish to get into a profound examination in this paper about which of the methods is ideal to serve a particular purpose, although it has a rich literature as well.)

\section{The Problems of Choosing a Method}

In the case of investment projects with orthodox cash flow patterns, each of the discounted cash-flow methods, if applied in an appropriate way, leads to the same qualification of economic efficiency, in other words, if one indicator considers the investment in question economically viable, then the other indicator will lead to the same conclusion. 'The well-known criteria of orthodox cash flow patterns are: a series of the difference of annual revenues and expenditures starts with negative amount or amounts and the sign of these differences changes only once. That is, from a point in time where this difference first turns into positive, this positive sign does not change.' (Illés [5], p. 22.)

Although it is true that for the qualification of an investment project with orthodox cash flow patterns or for determining whether the project in question can be considered economically viable or not, one correctly applied indicator of investment efficiency might be enough, the information content and expressiveness of the indicators are different, therefore the simultaneous application of several methods can help perform a wider analysis. The evaluation of investment alternatives by using several indicators can be considered more expedient because they can provide additional information to the analyses and help make more established decisions on investments. In addition, they do not usually require any considerable additional time, as they are essentially based on the same economic information. It has to be noted that some - otherwise correct - methods do not substantially increase the ability of making responsible investment decisions. Among others, they include profitability index.

The method of calculating net present value is primarily addressed in the finance literature. Some academics (such as Brealey and Myers [4], pp. 61-82.) believe that looking for the internal rate of return may lead to more results, whereas in the case of calculating net present value, only one result can be obtained as a solution. However, more internal rates are only typical of investments with non-orthodox cash flow patterns, in the case of investments with orthodox cash flow patterns there can be only one interest rate.

In Managerial Accounting, Garrison [6], when comparing net present value and the internal rate of return, states in the first sentence of the chapter that the calculation of net present value has got numerous advantages over the use of the method of the internal rate of return, followed by three nowadays perhaps debatable - advantages explained in detail that are listed below:

- The method of calculating net present value is easier to use,

- It is easier to estimate risk with the method of calculating net present value,

- The calculation of net present value provides more useful information than the internal rate of return.

(Garrison [6], p. 609.)

Similarly to Garrison's book, studies published before 2000 , often state that one of the advantages of the calculation of net present value over the internal rate is that net present value is relatively easy to calculate. Due to the achievements in information technology, it is possible to compute the internal rate of return by clicking on a single button in a simple computer program (eg. Excel).

The method of calculating net present value is not only recommended by the literature dealing with the assessment of the economic efficiency of investments, but sometimes it is also recommended to apply for setting up rankings. A common argument in favour of using net present value for setting up rankings is that this value shows the project's contribution to shareholder value, thus ensuring its maximization. In an article published in 2012, Illés [7] demonstrated clearly that the ranking made by the indicator of net present value did not lead to long-term maximization of shareholder value.

\section{Capital Budgeting Methods Applied in Europe}

This paper presents the findings of the research conducted in some European countries in a chronological order. (It is worth mentioning that the year of the given research and the year of its publication sometimes significantly differ.)

Although the research studies in the United Kingdom 
-referred to in the introduction - date back to a period of several decades, it cannot be stated that discounted cash-flow techniques have started to replace or supersede non-discounted methods over the course of time. Based on his own research findings and the research studies previously reviewed, Pike [8] carried out a longitudinal study of the practical use of four capital budgeting methods, his results are summarized in Table 1. (Although Pike conducted the research a long time ago, a lot of researchers still refer to his results and consider his research to be a fundamental. That is the reason why this paper gives a brief description of his results.)

Table 1. Capital budgeting methods used by corporations in the United Kingdom

\begin{tabular}{|c|c|c|c|c|}
\hline Method used & 1975 & 1980 & 1986 & 1992 \\
\hline Payback Period (PP) & $73 \%$ & $81 \%$ & $92 \%$ & $94 \%$ \\
\hline $\begin{array}{c}\text { Accounting Rate of } \\
\text { Return (ARR) }\end{array}$ & $51 \%$ & $49 \%$ & $56 \%$ & $50 \%$ \\
\hline $\begin{array}{c}\text { Internal Rate of Return } \\
\text { (IRR) }\end{array}$ & $44 \%$ & $57 \%$ & $75 \%$ & $81 \%$ \\
\hline $\begin{array}{c}\text { Net Present Value } \\
\text { (NPV) }\end{array}$ & $32 \%$ & $39 \%$ & $68 \%$ & $74 \%$ \\
\hline
\end{tabular}

Source: Pike [8], p. 82.

With the exception of the accounting rate of return, the frequency of all the remaining methods has considerably increased in the examined period. Despite the recommendations in the literature, the payback period is the method that is quantified by almost all British corporations. Of the two discounted cash-flow methods presented in the study, decision-makers preferred the internal rate of return to the net present value in the United Kingdom. In 1989 Sangster [9] carried out a survey among 500 major Scottish corporations and obtained similar results to that of Pike's. $78 \%$ of the respondents used the payback period for evaluating the efficiency of investments, $58 \%$ of them used the internal rate of return, $48 \%$ of them reported using the net present value while the least used technique was the accounting rate of return. As for Ireland, there are results of relatively recent research. The survey on capital budgeting techniques conducted by Kester and Robbins [10] in November 2009 revealed that the majority of managers of Irish companies applied net present value the most frequently which was closely followed by non-discounted payback period and then by internal rate of return. (The study did not provide responses in percentage). The accounting rate of return was the least frequently used indicator. The results of this survey slightly differed from the results of surveys previously conducted in the UK. The non-discounted payback period was ranked second and the net present value shifted from the third place to the first. (This study neither compared its findings with findings of previously conducted research studies nor addressed the the reasons of the shifts.)

In 2002 Brounen, Jong and Koedijk [11] asked corporate executives in four European countries (the United Kingdom, the Netherlands, Germany and France) about their investment decisions. Private and public companies employing at least 25 workers were involved in the research. It is worth mentioning that small-sized enterprises were also represented in the sample, though their approaches to the feasibility and realization of investments are completely different and they usually make decisions based on different aspects. 2000 British, German and French enterprises were involved in the sample together with 500 enterprises from the Netherlands but the response rate of the questionnaires was very low, reaching only $5 \%$ on average. Corporate executives were asked to evaluate the used techniques on a scale of 0 to 4 . This survey ended with the result that the payback period was favoured by the surveyed corporations during the preparation for their decisions on invenstments, which surprised even the researchers themselves. In terms of the techniques that take the time value of money into account, some difference could be observed in the preferences of corporate executives: in the case of the British and French enterprises the internal rate of return, while in the case of their Dutch and German peers the net present value was more frequently used when evaluating investment alternatives. It was interesting to observe that the use of the profitability index was more prevalent than the calculation of the net present value among the French enterprises. (The findings of the surveys carried out in the European countries are shown in Table 2.) The researchers also carried out a multivariate probit regression analysis in order to reveal the determining characteristics of the calculation methods (eg. the size of the firm, the qualification level of CEOs, whether the company is registered on the stock exchange etc.). The result of the performed regression analysis was - among others - that there was a significant positive relationship between the method used and the size of the firm as well as the presence in the stock exchange.

In 2003 and 2004 Hermes, Smid and Yao [12] carried out another research into the subject in the Netherlands. 250 enterprises were asked by email to take part in the survey and 42 filled-out questionnaires were returned. The enterprises were asked to evaluate how often they used a given capital appraisal technique on a scale of 0 to $4(0=$ never, $4=$ always). Comparing the data obtained by the survey in the Netherlands with the findings of the research carried out by Brounen, Jong and Koedijk [11] in 2002, it can be established that although there are slight differences in the resulting rates (due to the higher rate of small-sized enterprises in the sample taken in 2002), the ranking of the indices did not change in terms of the frequency of use. By performing a multivariate regression analysis, the researchers tried to find a relationship between the method used, the size of the firm and the age of CFOs. 'The results show that the choice for the NPV method is also determined by the size of the firm and the age of the CFO; both variables have a negative and statistically significant coefficient. This means that smaller firms and firms with older CFOs use the NPV method less often than larger firms and firms with younger CFOs do.' (Hermes, Smid and Yao [12], p. 21.) 
In 2002 the financial executives of the corporations listed in the Finnish stock exchange were asked by Liljeblom and Vaihekoski [13] about their decisions on investments. 32\% of the sent out questionnaires were returned. The first question in the questionnaire aimed at which of the capital budgeting methods were used either primarily or secondarily by the Finnish corporations for evaluating their investment projects. According to the study, they used the payback period and the internal rate of return as primary methods for the evaluation of their investments, and, unlike their peers in France, they did not prefer the profitability index. The authors compared the rates of using three methods, the payback period, the internal rate of return and the net present value to the findings of the previous researches carried out in Finland. According to the study published in 1975 by Honko and Virtanen [14], 43.5\% of the Finnish corporations regarded the internal rate of return as a primary indicator, as opposed to this figure, only $6.5 \%$ of them used the net present value as a primary indicator. In 1984 Virtanen [15] repeated the questionnaire survey which showed an even more significant difference between the two methods: $57.7 \%$ of the Finnish corporate executives preferred the internal rate of return as a primary indicator and only $2.5 \%$ of them (!) opted for the net present value.

Between 2005 and 2008, Daunfeldt and Hartwig [16] carried out a research in Sweden, partly for the reason of revealing whether corporate managers applied the capital budgeting methods recommended by the literature or not. Of the five methods I examined, the researchers reckoned the net present value and the profitability index among the ones recommended by the literature, and the internal rate of return, the payback period and the accounting rate of return were listed among the not recommended ones. In 2005 the questionnaires were sent out to 244 Swedish corporations listed in the Swedish stock exchange and 102 were returned for assessment. In 2008 the survey was carried out again, this time 249 questionnaires were sent to Swedish corporations and 88 of them were returned ready for further evaluation. To the question of 'how often do you use the following capital budgeting methods', the corporation managers were asked to give their answers on a scale of 0 to $4(0=$ never, $4=$ always $)$. Contrary to their Finnish counterparts, the most frequently used capital budgeting method by the Swedish corporations was the net present value: $61.14 \%$ of the respondents said that they always or often used this indicator in the phase of preparing a decision. The second most frequently used method was the payback period with a rate of $54.4 \%$, followed by the internal rate of return, the accounting rate of return and the profitability index. In order to broaden the analysis, the researchers carried out simple and multivariate regression analyses as well. They were looking for relationships among the size of the company, leverage, growth opportunities, the rate of paid dividends, sectoral affiliation, the planned debt ratio, the rate of foreign sales, the proportion of shares held by the management, the age and the level of education of CEOs and the method used. According to the analyses, the use of net present value, the internal rate of return and simple payback period is more typical of corporations rather than small-sized enterprises. The publicly-listed Swedish corporations with higher growth opportunities most often used the internal rate of return while profitability index was the least used method. High-leverage companies used payback period most often instead. Among companies with stricter debt targets, the use of two indicators, the accounting rate of return and the profitability index was the most significant. Companies with a higher dividend pay-out level preferred using the internal rate of return and profitability index. Management-owned companies as well as companies managed by older CEOs were in favour of using the accounting rate of return as a method while companies managed by CEOs with a higher education level mainly used the internal rate of return and discounted payback period.

In 2008 Brunzell, Liljeblom and Vaihekoski [17] carried out a survey in five Nordic countries, namely in Denmark, Finland, Iceland, Norway and Sweden. The time period that passed between the survey and its publication was long. Questionnaires were sent to 711 companies and 157 responses with a reposne rate of $22.1 \%$ were received. The most popular method was the net present value because $41.29 \%$ of the responded companies indicated this method to be one of their primary methods. Despite its theoretical problems, the payback period was the second most popular method $(25.16 \%)$. Only one-fifth of the responded companies used internal rate of return and $17.42 \%$ of the respondents applied accounting rate of return as a primary method when investment projects were evaluated. (The study did not provide the results broken down by countries. Thus the results shown in Table 3 are aggregated.) There were other research studies on this issue conducted earlier in Finnland and Sweden. The findings should have been compared. Since the survey carried out by Brunzell, Liljeblom and Vaihekoski [17] provide aggregated results, the comparison of data was impossible.

As for the Central and Eastern European region, a group of researchers formed by Andor, Mohanty and Tóth [18] carried out an empirical research. They asked 400 companies employing at least 25 people about their investment decisions by phone in 10 countries (Bulgaria, the Czech Republic, Croatia, Latvia, Lithuania, Poland, Hungary, Romania, Slovakia and Slovenia). First, they asked corporate managers if they used any capital budgeting method, then they asked them if they used any of the discounted cash-flow methods. The next question was whether they used other methods as well, such as the payback period, return of assets or return on equity but the researchers did not inquire about which method (or which of the methods) were effectively used by the companies applying those discounted ones that take the time value of money into consideration. $17 \%$ of the responding managers said that they did not use any capital budgeting method at all. Of those companies that performed calculations on economic efficiency in the course of preparing decisions on their investments, only $61 \%$ applied a discounted method regularly, the remaining $39 \%$ did not or 
very rarely used them. $87 \%$ of the companies using discounted cash-flow methods always calculated the payback time as well, while the same rate was only $68 \%$ among those companies that did not use any discounted methods.

A couple of years ago, in 2011 in Spain 2000 corporate managers of non-financial institutions were sampled about their investment decisions (Andrés, Fuente, San Martín [19]). Only 140 questionnaires were sent back, which amounted to the response rate of $7 \%$. The surveyed managers indicated the frequency of using particular capital budgeting techniques on a five-level scale. The results revealed that the majority of Spanish companies used non-discounted payback period $(75 \%)$ and internal rate of return $(74.1 \%)$ the most frequently. Net present value was also a popular method $(65.7 \%)$. In the summary the authors claimed that the popularity of payback period among Spanish CFOs is significantly higher than in other European and North American countries. What is interesting about the Spanish research, which differs from other research studies conducted in this issue is that even major companies use non-discounted payback period more frequently than net present value or internal rate of return.

A study published in 2014 (Wnuk-Pel [20]) provides an insight into capital budgeting practices of Polish companies. (The year of the questionnaire survey is not indicated.) Out of 100 Polish respondents, 53\% applied net present value, $47 \%$ used internal rate of return, $35 \%$ preferred non-discounted payback period and $15 \%$ favoured accounting rate of return always or almost always when the evaluation of investment projects was perfomed. The findings revealed that the surveyed Polish companies prefered the same capital budgeting methods as companies in industrial countries. However, the rate of the application of the methods was lower.

As for capital budgeting practices of small and mideum-sized enterprises in Serbia, a study was published in 2015 (Barjaktarovic at al. [21]). (The year of the questionnaire survey is not indicated.)The sample included 30 companies. Out of the overall number, 13 enterprises present micro companies, 8 enterprises are defined as small enterprises and 10 companies are defined as medium-sized enterprises. The results of this research showed that the SMEs and micro companies were most inclined to use a payback criterion as the capital budgeting technique (the average percent of usage regarding this technique by all three types of the companies was $68.8 \%$ ). Furthermore, the results showed that $58 \%$ of the companies most frequently used profitability index and $42 \%$ of the respondents used net present value as the investment criterion in project evaluation. Out of the surveyed companies up to $16 \%$ used internal rate of return and $8 \%$ applied accounting rate of return. (The diagram in the study does not contain exact values.)

(Table 2 summarizes all the information on the researches detailed in the above nine paragraphs.)

The author of the article conducted a considerably extensive survey on corpotrate investment decisions in Hungary. That is the reason why a separate chapter is devoted to the results of the Hungarian survey in this study.

Table 2. Capital budgeting methods most frequently used by corporate managers in some European countries

\begin{tabular}{|c|c|c|c|c|c|c|c|c|c|c|c|}
\hline Method used & $\begin{array}{l}\text { the UK } \\
(2002)\end{array}$ & $\begin{array}{l}\text { the } \\
\text { Netherl. } \\
(2002)\end{array}$ & $\begin{array}{c}\text { the } \\
\text { Netherl } \\
(2002- \\
2003)\end{array}$ & $\begin{array}{l}\text { Germany } \\
(2002)\end{array}$ & $\begin{array}{l}\text { France } \\
(2002)\end{array}$ & $\begin{array}{c}\text { Finland } \\
(2002)\end{array}$ & $\begin{array}{c}\text { Sweden } \\
(2005-2008)\end{array}$ & $\begin{array}{l}\text { Nordic } \\
(2008)\end{array}$ & $\begin{array}{l}\text { Spain } \\
(2011)\end{array}$ & $\begin{array}{l}\text { Poland } \\
\text { (2014) }\end{array}$ & $\begin{array}{l}\text { Serbia } \\
(2015)\end{array}$ \\
\hline $\begin{array}{c}\text { Payback } \\
\text { Period (PP) } \\
\end{array}$ & $69.23 \%$ & $64.71 \%$ & $79 \%$ & $50.00 \%$ & $50.88 \%$ & $22.9 \%$ & $54.40 \%$ & $25.16 \%$ & $75.0 \%$ & $35 \%$ & $68.8 \%$ \\
\hline $\begin{array}{c}\text { Accounting } \\
\text { Rate of Return } \\
\text { (ARR) }\end{array}$ & $38.10 \%$ & $25.00 \%$ & $2 \%$ & $32.17 \%$ & $16.07 \%$ & $6.3 \%$ & $23.83 \%$ & $17.42 \%$ & -- & $15 \%$ & cc. $8 \%$ \\
\hline $\begin{array}{l}\text { Internal Rate } \\
\text { of Return } \\
\text { (IRR) }\end{array}$ & $53.13 \%$ & $56.00 \%$ & $74 \%$ & $42.15 \%$ & $44.07 \%$ & $22.9 \%$ & $30.05 \%$ & $19.35 \%$ & $74.1 \%$ & $47 \%$ & $\begin{array}{l}\text { cc. } \\
16 \%\end{array}$ \\
\hline $\begin{array}{c}\text { Net Present } \\
\text { Value (NPV) }\end{array}$ & $46.97 \%$ & $70.00 \%$ & $89 \%$ & $47.58 \%$ & $35.09 \%$ & $18.8 \%$ & $61.14 \%$ & $41.29 \%$ & $65.7 \%$ & $53 \%$ & $42.0 \%$ \\
\hline $\begin{array}{l}\text { Profitability } \\
\text { Index (PI) }\end{array}$ & $15.87 \%$ & $8.16 \%$ & -- & $16.07 \%$ & $37.74 \%$ & $0.0 \%$ & $12.44 \%$ & -- & -- & -- & $58.0 \%$ \\
\hline
\end{tabular}

Source: own elaboration based on Brounen, Jong and Koedijk [11], p. 95; Liljeblom and Vaihekoski [13], p. 13.;Hermes, Smid and Yao [12], p. 31.; Daunfeldt and Hartwig [16], p.27. Brunzell, Liljeblom and Vaihekoski [17], p. 105.; Wnuk-Pel [20], p. 614.; Andrés, Fuente, San Martín [19], p. 46.; Barjaktarovic at al. [21], p. 6.

(this table includes the rates of the respondents selecting the answer options of 'always', 'almost always'/'often', or the rates of corporations using one as a primary method) 


\section{Capital Budgeting Methods Used in the United States}

The research duo, Graham and Harvey [22] made an attempt to explore the investment decisions made by US managers with the involvement of a fair number of companies in 1999. Their questionnaire was sent to the chief financial officers of 4,400 American companies, of which 392 pieces were returned in a suitable form for evaluation. The survey extended to small-sized enterprises and corporations alike. $40 \%$ of the surveyed companies represented the manufacturing sector, $15 \%$ of them operated in the financial sector and $13 \%$ belonged to the transportation and energy sectors. In the course of the survey conducted by Graham and Harvey in 1999, the respondents, using a scale ranging from 0 to 4 , were asked to mark how often they applied each capital budgeting method. (The results of the research in question are shown in Table 3).

The research led to the conclusion that large corporations had increasingly used net present value for evaluating investment projects while small-sized enterprises had still preferred using the payback period instead. This result is slightly different from the results of previous researches carried out mainly among corporations in the US, although it is true that this survey ranked the indicator of the internal rate of return in the first place as the most preferred method of evaluation but its advantage measured against net present value almost disappeared. For instance, according to a survey conducted in 1977 (Gitman and Forrester [23]) of the 103 responding corporations, only $9.8 \%$ were primarily used the calculation of net present value and $53.6 \%$ of them used the method of the internal rate of return. In 1984, another survey (Stanley and Block [24]) came to a similar conclusion: $65 \%$ of US companies also put the internal rate of return in the first place in the ranking of methods used for the evaluation of investments.

Graham and Harvey [22] included a number of characteristics of corporations as well as qualities of CEOs in their analysis, based on which it was found that ,large firms are significantly more likely to use net present value than small firms. There is no difference in techniques used by growth and nongrowth firms. Highly levered firms are significantly more likely to use net present value and internal rate of return than firms with small debt ratios. This is not just an artifact of firm size. In unreported analysis, we find a significant difference between high- and low-leverage small firms as well as high- and low leverage large firms. (...) We also find that CEOs with MBAs are more likely than non-MBA CEOs to use net present value. (...) Firms that pay dividends are significantly more likely to use net present value and internal rate of return than are firms that do not pay dividends. This result is also robust to our analysis by size. Public companies are significantly more likely to use net present value and internal rate of return than are private corporations. (...) Other than net present value and internal rate of return, the payback period is the most frequently used capital budgeting technique. This is surprising because financial textbooks have lamented the shortcomings of the payback criterion for decades. Small firms use the payback period almost as frequently as they use NPV or IRR. In untabulated analysis, we find that among small firms, CEOs without MBAs are more likely to use the payback criterion. The payback is most popular among mature CEOs. For both small and large firms, we find that mature CEOs use payback significantly more often than younger CEOs in separate examinations. Payback is also frequently used by CEOs with long tenure.' (Graham and Harvey [22], p. 6.)

In 2002, Ryan and Ryan [25] published the results of their research on the Fortune 1000 companies in the Journal of Business and Management. A two-page questionnaire was sent to all the companies included in the list and 205 questionnaires suitable for evaluation were returned. For each capital budgeting method, the respondents were asked to mark on a five-level Likert scale how frequently they used a particular method ('always' = 100 percent, 'often' = approximately 75 percent, 'a few times' = around 50 percent, 'rarely' = approximately 25 percent, 'never' $=0$ percent). The Fortune 1000 companies - in line with literature recommendations - favoured discounted cash-flow methods taking the time value of money into account, neither payback period nor the accounting rate of return was typical. However, the highest-revenue corporations in the US preferred the calculation of net present value among the discounted cash-flow methods. (The results of the empirical study by Ryan and Ryan [25] are also summarized in Table 3.) With the help of Pearson's chi-squared test, the authors revealed a positive relationship between the amount invested and the use of net present value and the internal rate of return, furthermore payback period and profitability index were more frequently used by firms with smaller capital budgets.

Table 3. The most frequently used capital budgeting methods used by managers in the US (including the rate of companies answering 'always', 'almost always' and 'often')

\begin{tabular}{|c|c|c|}
\hline Method used & $\begin{array}{c}\text { Graham - Harvey } \\
(1999)\end{array}$ & $\begin{array}{c}\text { Ryan - Ryan } \\
(2002)\end{array}$ \\
\hline Payback Period (PP) & $56.74 \%$ & $52.6 \%$ \\
\hline $\begin{array}{c}\text { Accounting Rate of } \\
\text { Return (ARR) }\end{array}$ & $20.29 \%$ & $15.4 \%$ \\
\hline $\begin{array}{c}\text { Internal Rate of Return } \\
\text { (IRR) }\end{array}$ & $75.61 \%$ & $76.8 \%$ \\
\hline Net Present Value (NPV) & $74.93 \%$ & $85.1 \%$ \\
\hline Profitability Index (PI) & $11.87 \%$ & $21.4 \%$ \\
\hline
\end{tabular}

Source: own edition based on Graham and Harvey [22], p. 40.; Ryan and Ryan [25], p. 13.

In 2008 Chen [26] conducted a questionnaire survey on corporate investment decisions in the United States of America. The questionnaires were sent to 600 publicly operating manufacturing companies. Only 115 responses were returned and assessed. The study investigated capital budgeting methods with emphasis on the time factor and its primary aim was to find out the proportion of companies that used discounted cash flow (DCF) techniques. However, the 
study did not identify which method decision-makers they preferred. The respondents had to indicate the importance of the method on a scale from 1 to $5(1=$ not important, $5=$ extremely important). It is worth noting that the question targeted the importance of the method and not the frequency of its use. The response rate amounted to 4.017, which indicates that managers consider the methods which include a time factor in calculations to be sufficiently important. (Since this referred study does not investigate particular methods, its findings cannot be included in Table 3.)

\section{Capital Budgeting Methods Applied in Hungary}

Since no research has been conducted on the application of capital budgeting methods in Hungary yet, this study attempts to investigate practices of processing companies operating in Hungary when they make investment decisions. A survey was carried out in summer of 2012.

In order to eliminate the greatest drawback of a simple random sampling (the accuracy and reliability of the sample can be enhanced only by increasing the size of the sample), a stratified sampling method was used. The companies were grouped by their turnover and were rendered into the sample by simple random selection, allocated in proportion to each stratum. As a result, the composition of the sample reflected the composition of the population according to each stratum.

The questionnaire survey was conducted partly by post and partly online. The questionnaire was sent to 500 companies by post and another 1000 of them received a hyperlink allowing them to fill out the questionnaire by clicking on it. Altogether 76 questionnaires fit for evaluation were returned by deadline, resulting in a $5.1 \%$ response rate. This return rate seems low but similarly low ratios have been experienced in similar surveys carried out elsewhere in the world, for instance Brounen, Jong and Koedijk [11] also reported a 5\% return rate on average. After receiving the questionnaire, some managers refused to fill out the questionnaire on the phone, mainly for two reasons: one of them was that all information related to investments were qualified as confidential business information, the other was that there had been no significant investments at their company in the previous five or six years. The data in the completed questionnaires were summarized in the Microsoft Excel spreadsheet application and an analysis was carried out with the help of the WinSTAT statistical programme package. In the course of the analysis, simple descriptive statistical methods such as distribution ratios, group averages were used, on the other hand, where it was possible, comparative statistical analyses were performed (correlation coefficient, chi-square test, discriminant analyses and variance analysis).

In the survey corporate managers had to evaluate how often they used a certain indicator on a five-grade scale and indicate which indicator they used primarily and secondarily in their analyses. (The results of the received responses are shown in Figure 1 and Table 4.)

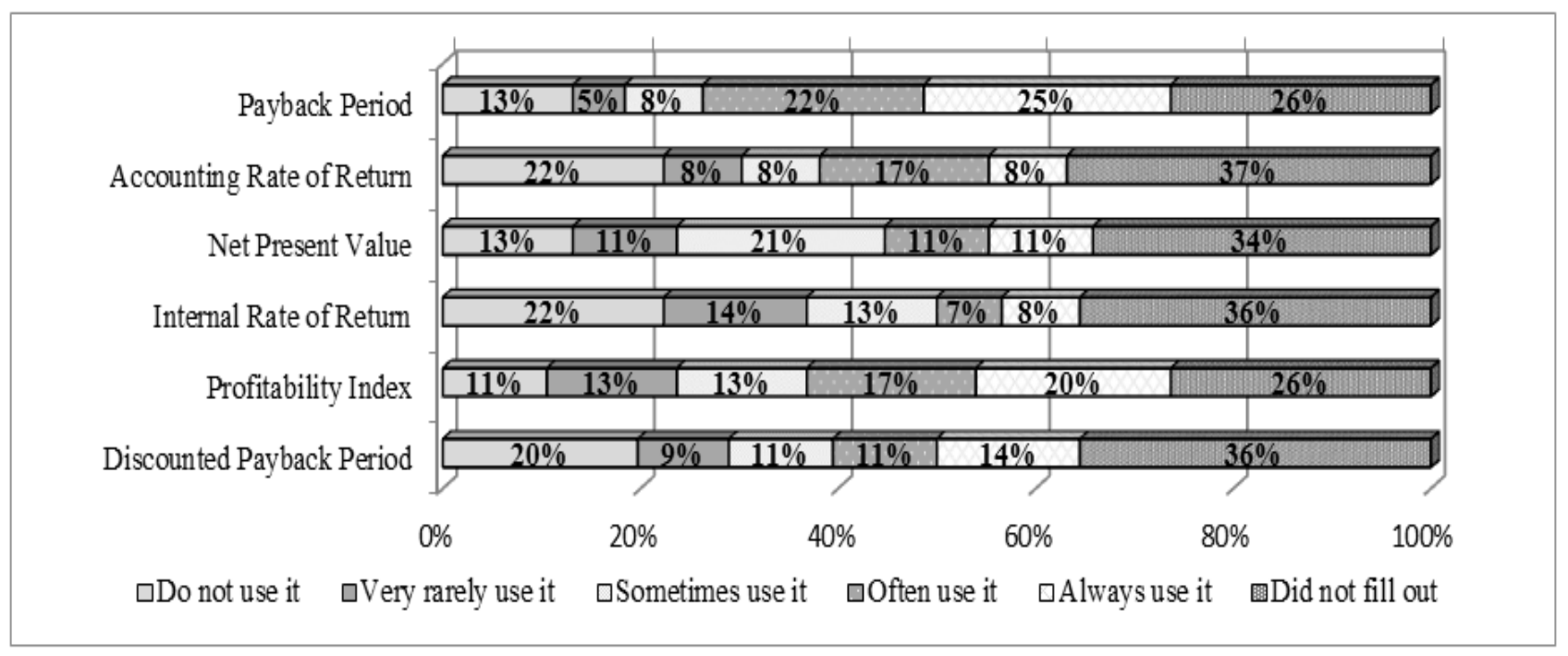

Source: Own elaboration based on the filled-out questionnaires

Figure 1. Indicators most frequently used for evaluating the economic efficiency of investments in Hungary 
Table 4. Indicators primarily or secondarily used for evaluating investment decisions by the Hungarian companies

\begin{tabular}{|c|c|c|}
\hline Method used & Primarily & Secondarily \\
\hline Payback Period (PP) & $45 \%$ & $24 \%$ \\
\hline Accounting Rate of Return (ARR) & $24 \%$ & $21 \%$ \\
\hline Internal Rate of Return (IRR) & $22 \%$ & $29 \%$ \\
\hline Net Present Value (NPV) & $11 \%$ & $24 \%$ \\
\hline Profitability Index (PI) & $30 \%$ & $25 \%$ \\
\hline Discounted payback period (DPP) & $24 \%$ & $17 \%$ \\
\hline Other method & $1 \%$ & $7 \%$ \\
\hline
\end{tabular}

Source: Own elaboration based on the filled-out questionnaires

Note: The rates exceed 100 percent because even though the respondents' attention was drawn to select only one primary and one secondary method, some corporate managers ticked off more primary and/or secondary methods.

$47 \%$ of the respondents always or often used the payback period, $37 \%$ of them the profitability index, $25 \%$ of them the accounting rate of return and the discounted payback period, $21 \%$ of them the net present value and $14 \%$ of them the internal rate of return to evaluate the economic efficiency of investments. At $45 \%$ of the responding companies the payback period, at $30 \%$ of them the profitability index were used as primary indicator, while at $29 \%$ of them the net present value and at $25 \%$ of them the profitability index were the secondary indicators for evaluating the economic efficiency of investments. (While interpreting the results, it has to be taken into account that the rates exceed $100 \%$ because some corporate managers ticked off more primary and/or secondary methods.)

Taking into account that several international researches had come up with the result that the indicators used for the assessment of the economic efficiency of investments differentiated according to company size, the analysis of the Hungarian companies was extended to examine whether this relationship was true to enterprises in the Hungarian processing industry as well. In doing so, the responses given to the questions about the applied capital budgeting methods were analyzed by company size with the help of group averages. (The group averages could obtain scores from 1 to 5.) Examining the frequency of using the indicators in such a way, the following observations can be made about the surveyed Hungarian enterprises in the processing industry (a summary of the results is provided in Table 5):

- The calculation of payback period is the most often used by small-sized enterprises and the least often by medium-sized enterprises. The accounting rate of return is also popular among small-sized enterprises and is the least often used by corporations.

- The calculation of net present value and the internal rate of return are most preferred by corporations. The former is the least often used by microenterprises while the latter is the least frequently used by medium-sized enterprises.

- The use of profitability index is mostly preferred by the decision-makers of small-sized enterprises and it is the least frequently used method by professionals at corporations.

- The discounted payback period is the most often used by corporations and the least preferred by medium-sized enterprises.

As it is shown in Table 5, it can be concluded that two non-discounted indicators together with the profitability index are mostly preferred by the decision-makers of small-sized enterprises in Hungary whereas the discounted cash-flow methods - except for the profitability index - are applied mostly by corporations.

Analyzing the group averages by the number of employees, similar results were obtained: enterprises employing the least number of workers mostly preferred the accounting rate of return and the profitability index, enterprises employing 50-249 people mainly chose payback period, and enterprises employing more than 250 people the most frequently applied net present value, the internal rate of return and discounted payback period during their assessment of economic efficiency. (The results are also demonstrated in Table 5.)

Table 5. The most frequently used indicators for evaluating investments divided by company size and the number of employees

\begin{tabular}{|c|c|c|c|c|c|c|c|}
\hline \multirow{2}{*}{ Method used } & \multicolumn{4}{|c|}{ Company size } & \multicolumn{4}{c|}{ Number of employees } \\
\cline { 2 - 9 } & Microenterprise & $\begin{array}{c}\text { Small-sized } \\
\text { enterprise }\end{array}$ & $\begin{array}{c}\text { Medium-sized } \\
\text { enterprise }\end{array}$ & Corporation & $0-49$ & $50-249$ & above 250 \\
\hline Payback Period (PP) & 3.22 & 3.91 & 3.08 & 3.33 & 3.41 & 3.68 & 3.22 \\
\hline Accounting Rate of Return (ARR) & 2.62 & 3.16 & 2.17 & 1.00 & 2.90 & 2.57 & 2.40 \\
\hline Net Present Value (NPV) & 2.67 & 2.88 & 2.92 & 4.67 & 2.75 & 2.83 & 3.71 \\
\hline Internal Rate of Return (IRR) & 2.41 & 2.29 & 2.08 & 4.67 & 2.25 & 2.72 & 3.43 \\
\hline Profitability Index (PI) & 3.08 & 3.67 & 3.08 & 2.00 & 3.38 & 3.33 & 2.83 \\
\hline Discounted payback period (DPP) & 2.95 & 2.73 & 2.50 & 5.00 & 3.00 & 2.47 & 3.43 \\
\hline
\end{tabular}

Source: Own elaboration based on the filled-out questionnaires 
It was not only interesting to examine if company size and the number of employees had any influence on the applied assessment indicators but it was also intriguing whether the qualification of those participating in the preparation of decisions had any correlation with the implemented methods. In order to find an answer to this question, the group averages were calculated by the professional qualification of the participants in the decision-making process. (The group averages could obtain scores from 1 to 5 , the results are detailed in Table 6.)

The analysis resulted in showing a divergence between the indicators used for evaluating investment projects and the directions of the professional qualification of the employees participating in the preparation process of decision-making. The non-discounted cash-flow methods were mainly favoured by decision-support groups with other professional qualification, the calculation of net present value, internal rate of return and payback period were mainly applied by decision-support groups consisting of engineers, and the profitability index was mostly preferred groups of economists. It was somewhat surprising to find that the profitability index, being technically appropriate, yet less expressive, was mainly preferred by decision-support groups formed by economists, since generally greater emphasis is given to the methodology of capital budgeting methods in the curriculum of Economics and study books written for students of Economics usually discuss each indicator in more detail.

These relationships were examined on the basis of ownership share as well. Companies with majority foreign ownership gave higher values for each of the six indicators, that is, companies with majority foreign ownership used all the six capital budgeting methods with greater frequency. (The resulting group averages are also shown in Table 6).

This study attempts to compare the findings of the Hungarian survey with the findings of international surveys on this issue. Since the survey was conducted in 2012, the results of surveys carried out around this time period were used. The studies conducted after 2010 served as a basis for comparison. Survey data from Spain, Poland and Serbia were available (There are no available research results from the USA after 2010, so this country is not included in the comparison table). Table 7 shows the survey data of four countries to make comparison easy.

The non-discounted payback period was the most frequently used investment-efficiency method in the evaluation of investment projects in all the investigated countries apart from Poland. None of the surveyed countries used accounting rate of return, the second non-discounted method very often. As for discounted methods, Hungarian and Serbian corporate managers preferred profitability index, whereas Spanish and Polish managers favoured internal rate of return and net present value.

Table 6. The most frequently used indicators for evaluating investments divided by the share of ownership and the qualification of participants in the preparation of decision-making

\begin{tabular}{|c|c|c|c|c|c|}
\hline \multirow{2}{*}{ Method used } & \multicolumn{2}{|c|}{ Share of ownership } & \multicolumn{2}{c|}{ Qualification of participants in the preparation of decision-making } \\
\cline { 2 - 6 } & $\begin{array}{c}\text { Domestic } \\
\text { majority }\end{array}$ & $\begin{array}{c}\text { Foreign } \\
\text { majority }\end{array}$ & Mainly engineers & Mainly economists & $\begin{array}{c}\text { Mainly persons with } \\
\text { other qualifications }\end{array}$ \\
\hline Payback Period (PP) & 3.44 & 3.69 & 3.39 & 3.50 & 3.89 \\
\hline Accounting Rate of Return (ARR) & 2.62 & 2.91 & 2.17 & 2.80 & 3.50 \\
\hline Net Present Value (NPV) & 2.79 & 3.33 & 3.04 & 2.83 & 2.37 \\
\hline Internal Rate of Return (IRR) & 2.35 & 2.67 & 2.39 & 2.33 & 2.11 \\
\hline Profitability Index (PI) & 3.29 & 3.36 & 3.20 & 3.86 & 3.33 \\
\hline Discounted payback period (DPP) & 2.76 & 3.16 & 3.06 & 2.67 & 2.43 \\
\hline
\end{tabular}

Source: Own elaboration based on the filled-out questionnaires

Table 7. Capital budgeting methods most frequently used by corporate managers in Hungary, Spain, Poland and Serbia

\begin{tabular}{|c|c|c|c|c|}
\hline Method used & $\begin{array}{c}\text { Hungary } \\
(2012)\end{array}$ & $\begin{array}{c}\text { Spain } \\
(2011)\end{array}$ & $\begin{array}{l}\text { Poland } \\
(2014)\end{array}$ & $\begin{array}{l}\text { Serbia } \\
(2015)\end{array}$ \\
\hline Payback Period (PP) & $47 \%$ & $75.0 \%$ & $35 \%$ & $68.8 \%$ \\
\hline Internal Rate of Return (IRR) & $15 \%$ & $74.1 \%$ & $47 \%$ & cc. $16 \%$ \\
\hline Net Present Value (NPV) & $22 \%$ & $65.7 \%$ & $53 \%$ & $42.0 \%$ \\
\hline Profitability Index (PI) & $37 \%$ & -- & -- & $58.0 \%$ \\
\hline
\end{tabular}

Source: own elaboration based on Szucsne Markovics [29], p. 21.; Wnuk-Pel [20], p. 614.; Andrés, Fuente, San Martín [19], p. 46.; Barjaktarovic at al. [21], p. 6.

Note: This table includes the rates of the respondents selecting the answer options of 'always', 'almost always'/'often', or the rates of corporations using one as a primary method. 


\section{Conclusions}

In today's relevant literature on business management, both the essential non-discounted and discounted cash-flow methods can be found, though the authors present the substance of each of the methods with different elaboration and thoroughness, sometimes in a slightly misleading way. However, there seems to be a unity in recommending the use of those discounted methods in practice that take the time value of money into account.

Both the international and the domestic literature include works (eg. Brealey and Myers [4], Sabjányi [27], Gázmár [28]) that overemphasize the benefits of the calculation of the net present value. From the viewpoint of business management, the preferred use of the net present value over the other discounted cash-flow methods does not seem to be well-founded. Its reasons are as follows:

- The information content of the net present value is rather scarce because it hides the real rate of return achievable by the project. Some other methods can be found among the discounted ones with better expressiveness, more definite consequence and presumably easier understanding by corporate professionals than the indicator of the net present value.

- It is inevitable to determine the discount rate beforehand for the calculation of the net present value, the rate of which considerably affects the outcome of the calculation. For determining the discount rate, there is no objective and exact method, it is mostly settled by estimation in corporate practice. The inappropriate determination of the discount rate might lead to erroneous decisions in some cases.

The results of the researches carried out in the European countries and in the US showed that the corporate professionals often calculate the payback period, however some researchers indicated that this indicator was only determined for orientation, investment decisions were primarily evaluated by some of the discounted cash-flow methods. It was also obvious that among the methods using the time value of money, the methods of the net present value and the internal rate of return were the two most frequently applied ones in the surveyed countries. The use of the profitability index was less typical.

The findings of the empirical survey carried out in Hungary were slightly different. Similarly to the other countries, the payback period, which raised some theoretical and methodological problems, was also determined by a rather high number of Hungarian corporations. However, they did not do it only for the reason of orientation but they also used this indicator as the primary method for evaluating investment projects. As for discounted cash-flow methods, a significant number of Hungarian decision-makers preferred profitability index. The use of net present value and internal rate of return, the two indicators often recommended by authors and applied by corporations in Europe and in the US, were less frequently used by the surveyed Hungarian companies.

A number of researcher studies sought certain relationships between the methods used for the evaluation of investment projects and corporate characteristics or certain executive qualities. Based on the available European and American studies as well as on the empirical survey conducted in Hungary, it can be ascertained that the indicators used for the evaluation of the economic efficiency of investments are differentiated by the size of companies: non-discounted cash-flow methods are rather preferred by small-sized enterprises while discounted techniques are mostly favoured by decision-makers of large corporations. This is due to several factors. One of the reasons is general and is related to specific features of the method: non-discounted methods are easy to use, are clear and transparent and do not require particular mathematical skills. The second reason is related to coporate characteristics that are country specific: in small and medium-sized enterprises in some countires (including Hungary) professionals without any economic or financial educational background prepare investment decisions. In several European countries managers of small enterprises are short of well-qualified staff in contrast to their larger counterparts and are likely to simplify the investment process, which can be attained in two ways: they either leave out one or more stages of preparation process of investment decison or do not peform activities as sufficiently as major companies. This is because managers of small enterprises, who are owners of these businesses, are able to fully oversee and manage corporate processes. In this corporate context it frequently happens that managers, that is owners themselves, are engaged in preparing investment decisions without having any financial or economic qualification. Consequently, they lack the knowledge of or fail to apply sophisticated discount valuation methods. By contrast, managers of large corporations are not able to fully oversee complete economic processes and their specific areas in great detail. This is the reason why they are more likely to involve representatives from different areas (financiers, production managers, etc.) in preparing investment decisions. Consequently, professionals with solid and reliable economic and financial backgrounds calculate economic efficiency of the investment. In addition, the rate of micro, small and medium-sized enterprises is high in Hungary and 98\% of processing companies belong to this group.

To sum up, although a relatively high number of American companies calculate non-discounted payback period, (according to the referred survey, over half the sampled companies use this method), net present value and internal rate of return are given greater significance. By contrast, in some European countries, including Spain, Serbia and Hungary, a great proportion of companies frequently apply non-discounted payback period to evaluate investment projects. They are very likely to use this method because it is simple. They calculate this indicator for information and 
explorary purposes, whereas in Europe - mostly in less developed countries - the shortage of sufficient trained and qualified staff involved in preparing investment decisions and the high proportion of micro, small and medium-sized enterprises may provide an explanation for the phenomenon. Presumably, there may be also other factors and peculiarities that contribute to the frequent application of non-discounted payback period, for instance, the age of corporate professionals (some surveys revealed that older decision-makes gave preference to non-discounted methods of investment appraisal), established and rooted corporate habits or perhaps, inefficient capital markets, etc. Further research is required to explore these factors and to identify the reasons for such great popularity of profitability index and not other discounted methods in corporate practices in some countries (France, Serbia and Hungary), despite the recommendations offered in literature.

\section{REFERENCES}

[1] R. W. Mills, P. J. A. Herbert. Corporate and Division Influence in Capital Budgeting: A study of Corporate Divisional Practice in Large U.K. Companies. The Chartered Institute of Management Accountants, London, U.K. 1987.

[2] R. H. Pike. An Empirical Study of the Adoption of Sophisticated Capital Budgeting Practices and Decision-Making Effectiveness. Accounting and Business Research, Vol. 18, No. 72, 341-351. 1988.

[3] M. Illés. Vezetői gazdaságtan (Managerial Accounting). Kossuth Kiadó. Budapest, Hungary. 2002.

[4] R. A. Brealey, S. C. Myers. Principles of Corporate Finance. McGraw-Hill Inc. United States of America. 61-82. 1981

[5] M. Illés. Fisher's Rate and Aggregate Capital Needs in Investment Decisions. Theory, Methodology, Practice. Club of Economics in Miskolc, Vol. 10, No. 1, 21-32. 2014.

[6] R. H. Garrison. Managerial Accounting. Business Publications Inc., Plano, Texas, United States of America, 1985.

[7] M. Illés. Links between Net Present Value and Shareholder Value from a Business Economics Perspective. Theory, Methodology, Practice. Club of Economics in Miskolc, Vol. 8, No. 2, 31-36. 2012.

[8] R. H. Pike. Longitudinal Survey On Capital Budgeting Practices; Journal of Business Finance \& Accounting, Vol. 23, No.1, 79-92. 1996.

[9] A. Sangster. Capital Investment Appraisal Techniques: A Survey of Current Usage. Journal of Business Finance \& Accounting, Vol. 20, No. 3, 307-333. 1993.

[10] G. Kester, G. Robbins. The Capital Budgeting Practices of Listed Irish Companies: Insights from CFOs on their investment appraisal techniques; The Journal of the Global Accounting Alliance, Vol. 2. No. 2. 1-5. 2011. Online available from http://www.gaaaccounting.com/the-capital-bu dgeting-practices-of-listed-irish-companies-insights-from-cf os-on-their-investment-appraisal-techniques, Retrieved: April 2016.

[11] D. Brounen, A. Jong, K. Koedijk. Corporate Finance in Europe: Confronting Theory with Practice. Financial Management, Vol. 33, No. 4, 71-101. 2004.

[12] N. Hermes, P. Smid, L. Yao. Capital Budgeting Practices: A Comparative Study of the Netherlands and China. 2006. Online available from http://som.eldoc.ub.rug.nl/FILES/repo rts/themeE/2006/06E02/06E02_Hermes.pdf, Retrieved: March 2012.

[13] E. Liljeblom, M. Vaihekoski. Investment Evaluation Methods and Required Rate of Return in Finnish Publicly Listed Companies. Finnish Journal of Business Economics, Vol. 53, No. 1, 9-24. 2004.

[14] J. Honko, K. Virtanen. The investment process in Finnish industrial enterprises. A study of the capital investment planning and control process in the fifty largest Finnish industrial enterprises. Helsinki School of Economics, Helsinki, Finland, 1975.

[15] K. Virtanen. Tulosyksikköorganisaation ohjaus. (Control in Profit-center Organisations) Weilin+Göös, Helsinki, Finland, 1984.

[16] S-O. Daunfeldt, F. Hartwig. What Determines the Use of Capital Budgeting Methods? Evidence from Swedish listed companies. 2012. Online available from http://www.hui.se/ MediaBinaryLoader.axd?MediaArchive_FileID=17edc3a8-0 911-4613-813e-fdf1 ce965da0\&FileName=HUIwp57.pdf\&M ediaArchive_ForceDownload=true, Retrieved: March 2012.

[17] T. Brunzell, E. Liljeblom, M. Vaihekoski. Determinants of Capital Budgeting Methods and Hurdle Rates in Nordic Firms. Accounting and Finance, Vol. 53, No. 1. 85-110. 2013. Online available fromhttps://www.researchgate.net/publicati on/236624221_Determinants_of_capital_budgeting_method s_and_hurdle_rates_in_Nordic_firms, Retrieved: April 2016.

[18] Gy. Andor, S. K. Mohanty, T. Tóth. Capital Budgeting Practices: A Survey of Central and Eastern European Firms. 2011. Online available from http://www.efmaefm.org/0EFM AMEETINGS/EFMA\%20ANNUAL\%20MEETINGS/2011Braga/papers/0118.pdf, Retrieved: March 2012.

[19] P. Andrés, G. Fuente, P. San Martín. Capital budgeting practices in Spain. Business Research Quarterly, Vol. 18. 2014. 37-56. Online available from http://www.sciencedirect .com/science/article/pii/S2340943614000656, Retrieved: April 2016.

[20] T. Wnuk-Pel. The practice and factors determining the selection of capital budgeting methods - evidence from the field. Procedia - Social and Behavioral Sciences, Vol. 156. 2014. 612-616. Online available from http://www.sciencedir ect.com/science/article/pii/S1877042814060704; Retrieved: April 2016

[21] L. Barjaktarovic, R. Pindzo, K. Dulic, A. Vjetrov. The Analysis of Capital Budgeting Techniques Implemented by Small and Medium-sized Enterprises in Serbia. Contemporary Financial Management, 2015. 4-8. Online available fromhttp://finiz.singidunum.ac.rs/portal/wp-conten t/uploads/sites/3/2015/12/4-8.pdf, Retrieved: April 2016

[22] J. R. Graham, C. R. Harvey. The theory and practice of corporate finance: evidence from the field. Journal of Financial Economics, Vol. 60, No. 2-3. 187-243. 2001. 
[23] L. J. Gitman, J.R. Jr. Forrester. A survey of capital budgeting techniques used by major U.S. firms. Financial Management, Vol. 6, No. 3. 66-71. 1977.

[24] M. T. Stanley, S. B. Block. A Survey of Multinational Capital Budgeting. The Financial Review, Vol. 19, No. 1. 36-54. 1984.

[25] P. A. Ryan, G. P. Ryan. Capital Budgeting Practices of the Fortune 1000: How Have Things Changed? Journal of Business and Management, Vol. 8, No. 4, 1-16. 2002.

[26] S. Chen. DCF Techniques and Nonfinancial Measures in Capital Budgeting: A Contingency Approach Analysis. Behavioral Research in Accounting, Vol. 20. No. 1. 13-29.

[27] L. Sabjányi. Beruházási döntések a gyakorlatban (Investment decisions in practice). Külkereskedelmi Föiskola. Budapest, Hungary. 1994.

[28] L. Gázmár. A beruházás költsége és a megvalósítás ajánlati ára (The cost of investment and the bid price of its realization). Energiagazdálkodás, Vol. 36, No. 1, 4-8. 1995.

[29] K. Szucsne Markovics. Empirical Research on the Process and Methods of Preparing Investment Decisions in Case of Domestic Manufacturing Companies, Ph.D. Theses, University of Miskolc, Miskolc, Hungary. 2014. Online available from http://midra.uni-miskolc.hu/jadox/portal/displ ayImage.psml?offset $=1 \&$ docID $=17998 \&$ secID $=11859 \&$ libr aryId $=-1 \&$ limit $=10 \&$ pageSet $=$ newLine $\&$ result Type $=0 \&$ sche maId $=$ null\&action $=$ browse $\&$ site $=$ search \& type $=$ advanced \&o rderBy=0, Retrieved: April 2016 